\title{
PENDERITAAN MENURUT ROMA 8:18-25 DAN IMPLIKASINYA BAGI GEREJA TUHAN MASA KINI
}

\author{
Iwan Setiawan
}

\section{PENDAHULUAN}

Di dunia ini manusia tidak dapat menghindari penderitaan. Berbagai usaha dilakukan oleh manusia agar terhindar dari penderitaan. Namun penderitaan tetap melanda manusia dengan berbagai bentuk, baik yang nampak di kasat mata, maupun yang tidak. Yang nampak secara kasat mata melihat adalah misalnya mengalami berbagai bentuk bencana, gangguan kesehatan, penderitaan dalam hal ekonomi, penderitaan karena ulah orang lain atau ulahnya sendiri, penderitaan karena dilengserkan dari sebuah kedudukan tertentu, dan sebagainya. Penderitaan yang tidak nampak di kasat mata, misalnya: kepedihan hati karena kedukaan atau kehilangan seseorang yang sangat dikasihi atau karena difitnah dan sebagainya. Dan penderitaan karena dosa, termasuk yang tidak selalu bisa dilihat oleh kasat mata.

Sementara itu tiap manusia pun memiliki kemampuan dan kecenderungan untuk menafsirkan penderitaan yang dialami oleh sesamanya. Yang sering terjadi adalah dihubungkan dengan dosa orang yang sedang mengalami penderitaan tersebut. Pandangan teologi tertentu bisa berbeda dengan yang lain dalam menilai sebuah penderitaan. Teologi sukses menegaskan bahwa penderitaan pasti sebagai konsekwensi dosa, sehingga ketika seseorang sudah diampuni dosanya, maka Tuhan pasti akan memberinya kesuksesan dalam segala hal. Karena itu orang berbondong untuk mengalami kesuksesan itu. Orang Kristen tidak akan mengalami penderitaan, tidak akan mengalami kerugian, malapetaka, sakit, kegagalan, ataupun meninggal. Orang Kristen pasti akan diberkati Tuhan secara melimpah, dalam usaha atau pekerjaannya, dalam keluarganya, dalam pelayanannya, dan seterusnya. Tetapi fenomena yang ada, tidak sedikit orang Kristen, bahkan hamba Tuhan sekalipun, tidak terluput dari berbagai bentuk penderitaan. Dengan ada perbedaan penafsiran atau pemahaman terhadap penderitaan, maka penulis tertarik untuk membahas topik ini berdasarkan Roma 8:18-25. 


\section{BAB I}

\section{ASAL-USUL PENDERITAAN}

Pada mulanya Allah menciptakan manusia dan menghendaki agar manusia dapat mencerminkan hidup sebagai ciptaan Allah yang mulia, yaitu segambar dan serupa dengan Allah. ${ }^{1}$ Berkaitan dengan istilah "segambar dan serupa dengan Allah," Lempp menuliskan bahwa: "manusia adalah tujuan dan mahkota segala makhluk, secara lahiriah dan batiniah diciptakan Allah, menurut Allah, seakhlak, sebakat, setabiat, sewatak dengan Allah, dan semuanya ditiru menurut aslinya." ${ }^{2}$ Hal ini pun dikemukakan oleh Hoekema, yang menyatakan bahwa sementara Allah menciptakan setiap hewan "menurut jenisnya" (Kej. 1: 21, 24-25), hanya manusia yang diciptakan menurut gambar dan rupa Allah (Kej. 1: 26-27). ${ }^{3}$ Maka saat manusia bermula dari tangan Sang Pencipta, ia tidak rusak, bobrok atau berdosa; manusia berada pada posisi yang baik, tidak bersalah dan kudus. Apa pun yang terdapat pada diri manusia saat ini, yang jahat atau menyimpang, bukan merupakan bagian dari penciptaan yang semula: manusia sangat baik adanya, akan tetapi iblis berhasil menggoda manusia pertama untuk memberontak dan tidak mentaati perintah-Nya. Akibatnya manusia jatuh ke dalam dosa dan mengakibatkan hubungan antara Allah dan manusia terputus (Kej. 3). Berkenaan dengan istilah "dosa," Hadiwijono menuliskan: "akan tetapi manusia memberontak terhadap Tuhan Allah. Ia tidak mau tunduk pada perintah Allah. Oleh karena itu manusia terputus hubungannya dengan Tuhan Allah." 4 Hal ini pun dikemukakan oleh Michaeli yang menyatakan bahwa:

Walaupun manusia memiliki kuasa untuk melakukan tuntutan Allah, namun manusia tidak mentaati Allah. Manusia ingin menjadi tuan atas dirinya sendiri, ingin menggantikan Allah dan ingin hidup tanpa Allah, Bapa-nya, maka timbullah kekacauan. Setiap kehidupan manusia menjadi rusak, dalam pekerjaanya, keluarganya, dan hubungan dengan sesama manusia timbul penderitaan, iri hati, kebencian dan kematian. Inilah dosa. Tak ada

${ }^{1}$ Louis Berkhof, Teologia Sistematika, Doktrin Manusia Vol. 2, (Jakarta: LRI, 1995), 45

2 Walter Lempp, Tafsiran Alkitab Kejadian 1:1 - 4:26, (Jakarta: BPK Gunung Mulia, 1987), 36-40

3 Anthony Hoekema, Manusia: Ciptaan Menurut Gambar Allah, (Surabaya: Momentum, 2003), 16

${ }^{4}$ Harun Hadiwijono, Iman Kristen, (Jakarta: Gunung Mulia, 2000), 244 
seorang pun yang bebas dari dosa. ${ }^{5}$

Akibat inilah yang harus ditanggung oleh manusia setelah jatuh dalam dosa, bahkan keterpisahan antara Allah dan manusia (Kej. 3:15) dan yang lebih menyedihkan lagi manusia harus mengalami penderitaan (Kej. 3:16-19). Berkaitan dengan hal ini Pfeiffer dan Harrison menuliskan bahwa: "kesukaran jasmaniah, kerja keras dan kelelahan yang mengecewakan serta perjuangan yang berat ditetapkan sebagai nasib si laki-laki yang dengan pasti dihukum sebagai orang berdosa." Hal ini pun dikemukakan oleh Epp, yang menyatakan bahwa: "oleh karena dosa Adam dan Hawa, Allah mengusir mereka keluar dari taman itu kepada suatu hidup penderitaan dan bekerja keras dengan membanting tulang. ${ }^{7}$ Keadaan ini terus berlanjut mulai dari keturunan Adam yaitu Kain dan Habel, bangsa Israel, nabi-nabi, raja-raja, para Rasul, orang-orang percaya, bahkan Tuhan Yesus sendiri turut menderita akibat dosa manusia. Namun Kristus menderita bukan karena dosa-Nya melainkan karena dosa manusia. Epp menambahkan bahwa:

Ia menderita di dalam tubuh, mental dan roh-Nya agar Ia dapat membayar hukuman dosa. Bukan dosa-Nya melainkan dosa manusia. Dan penderitaan-Nya itu tidak sia-sia. Orang-orang yang sudah menerima Dia sebagai Juruselamat, mereka akan menerima hidup yang kekal. ${ }^{8}$

Ada beberapa fenomena yang terjadi sekarang ini yaitu bahwa ketika hidup sebagai orang Kristen, justru seolah-olah lebih banyak menanggung penderitaan dibandingkan penderitaan dunia yang sudah ada. Penderitaan adalah kata yang sering dihindari oleh manusia termasuk orang percaya. Selain itu situasi zaman sekarang yang semakin menekan umat manusia, seperti yang dikatakan Tuhan Yesus bahwa zaman akhir dunia ini ditandai bukan oleh perdamaian, melainkan oleh peperangan yang bertambah-tambah (Mat. 24:6).

Fenomena yang lain mengenai kesaksian gereja-gereja, banyak martir di negara-negara komunis yang menjadi korban kekerasan dan penindasan, yang mengakibatkan penderitaan. Mengenai Indonesia,

${ }^{5}$ Frank Michaeli, Bagaimana Memahami Perjanjian Lama, (Bandung: Kalam Hidup, 1972), 8-9

${ }^{6}$ Charles F. Pfeiffer \& Everett F. Harrison, Tafsiran Alkitab Wycliffe Vol I, (Malang: Gandum Mas, 2004), 41

7 Theodore H. E, Mengapa Orang-Orang Kristen Menderita, (Jakarta: Mimery Press, 1991), 25

${ }^{8}$ Ibid., 29 
meskipun bukan negara komunis atau negara terlarang untuk Injil, namun ratusan gereja telah dirusak dan dibakar, yang mengakibatkan korban yang cukup banyak. Bahkan Majalah Tempo mencatat hasil Konfensi Wali Gereja Indonesia dan menegaskan bahwa jumlah gereja yang telah dirusak hingga Januari 2004 adalah 922 gereja. $^{9}$

Ada cukup banyak kesaksian tentang penderitaan orang percaya karena iman mereka kepada Kristus, namun tidak dapat dipungkiri bahwa masih banyak orang percaya yang belum memahami arti penderitaan itu. Hal ini nampak pada seringnya jemaat disuguhkan Firman Tuhan yang menawarkan kesenangan hidup belaka, tanpa harus mengalami penderitaan. Karena itu mereka lebih banyak melarikan diri, putus asa dan kecewa ketika mengalami penderitaan, padahal sesungguhnya penderitaan tidak dapat dihindari, namun yang dimaksudkan penulis adalah cara menanggapi penderitaan itu harus sesuai dengan apa yang Tuhan ajarkan, yaitu bahwa penderitaan yang dialami manusia itu tidak sebanding dengan kemuliaan yang akan dinyatakan (Rm. 8:18).

Dari fenomena-fenomena di atas, jelas bahwa penderitaan memang terjadi dalam kehidupan orang percaya, namun ternyata ada juga konsep-konsep yang keliru mengenai penderitaan yang mempengaruhi cara berpikir manusia termasuk orang percaya, di antaranya adalah Theologia Sukses. Theologia Sukses atau Theologia Kemakmuran, lahir karena pengaruh perkembangan dunia yang semakin materialistis, di mana uang dan materi dipuja-puja dan dikejar. Herlianto mengutip rumusan Yakub Nahuway mengenai Teologia Sukses, sebagai berikut:

Yesus-lah jawaban dari segala pergumulan, masalah, sakit penyakit, beban hidup yang berat, keputusasaan, bahkan dosa itu sendiri yang menjadi penyebab utama malapetaka, penderitaan dan kesusahan manusia. "Pandai, benar, adil, dan jujur" adalah empat kelengkapan yang menuntun hidup ini kepada jalan sukses, bahagia dan damai sejahtera. ${ }^{10}$

Para penganut teologi ini juga menekankan bahwa kesuksesan di atas telah disediakan Allah bagi setiap orang Kristen. Hanya saja, Allah telah menetapkan instrumen atau syarat untuk menerima kesuksesan tersebut, yaitu melalui iman. Penekanan pada "iman" ini membuat Teologi Kemakmuran seringkali disebut sebagai Teologi Iman (Theology of Faith). 2004), 64

${ }^{9}$ Setiyardi Y., Tomi Aryanto, \& Ayu Cipta, (Majalah Tempo, Edisi 21 November

${ }^{10}$ Herlianto, Teologia Sukses antara Allah dan Mamon, (Jakarta: BPK Gunung Mulia, 1993), 10; Yakub Nahuway, Jalan ke Surga telah Ada, (Jakarta: GBI Mawar Saron, 1990), 9,14 
Istilah lain yang mirip dan sering dipakai adalah Word-Faith Theology. Menurut mereka, iman bukan hanya apa yang ada dalam hati orang percaya, tetapi harus dibuktikan secara konkret melalui perkataan positif (Robert Schuller, Norman Vincent Peale), visualisasi (Kenneth Copeland; Yonggi Cho), maupun investasi materi dalam bentuk persembahan (Oral Roberts). ${ }^{11}$

Doktrin kemakmuran mulai populer di Amerika melalui pelayanan TV evangelist dan para pengkhotbah dari denominasi Pentakosta maupun kharismatik. Mereka menekankan bahwa Allah menginginkan semua orang Kristen untuk sukses dalam segala hal, termasuk secara jasmani. Para penganut ajaran ini menyatakan bahwa tujuan dari kesuksesan jasmaniah ini adalah untuk mendanai pekabaran Injil ke seluruh dunia. Tujuan seperti ini dianggap mendapat dukungan dari Ulangan 8:18 "Dialah yang memberikan kepadamu kekuatan untuk memperoleh kekayaan, dengan maksud meneguhkan perjanjian". ${ }^{12}$ Sebab itu akibat dari pengajaran ini tidak sedikit dari orang Kristen yang telah jatuh imannya karena tidak sanggup ketika menerima perlawanan-perlawanan yang membuat mereka menderitakan, sehingga akhirnya mereka kecewa, putus asa, dan tidak berdaya menghadapi penderitaan karena mereka tidak sanggup melihat makna rencana Allah yang rahmani di balik penderitaan itu.

Dengan melihat permasalahan di atas, maka judul penelitian ini adalah "Penderitaan Menurut Roma 8:18-25 dan Implikasinya bagi Gereja Tuhan Masa Kini." Penulis berharap agar kajian ini dapat memberikan kontribusi bagi orang percaya dalam kehidupan sehari-hari dan dalam persekutuan orang percaya.

\section{BAB II PENDERITAAN MENURUT ROMA 8:18-25}

Pada bab ini, akan dibahas beberapa kebenaran tentang penderitaan menurut Roma 8:18-25.

\section{Penderitaan Orang Kristen Tak Sebanding dengan Kemuliaan (ay 18)}

Dalam memulai ayat ini Paulus menulis pernyataannya dengan kata

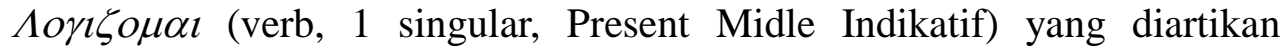
memperhitungkan, menganggap, mengira, berpikir, berpendapat. Kata ini berasal dari kata $\lambda \varepsilon \gamma \omega$ (lego) yang diterjemahkan: berkata, berbicara,

11 Yakub Tri Handoko, Theologia Kemakmuran, (Tenggilis Mejoy: Sekolah Alkitab Malam GKKA, 7 Mei 2007), 1

12 Ibid., 1 
mengucapkan, berpendapat. ${ }^{13}$ Namun dalam konteks ayat ini lebih tepat jika diterjemahkan: aku berpendapat. Bentuk Indikatif yang dimaksud adalah suatu tindakan yang menyatakan bahwa pernyataan itu sebagai suatu kepastian atau keyakinan. Keyakinan di sini adalah keyakinan yang bertentangan dengan kenyataan (Rm. 3:28; 4:3). Sebagaimana orang percaya dibenarkan oleh Allah meski mereka sendiri tidak memiliki kebenaran nyata, begitu pula Paulus yakin akan kebesaran kemuliaan yang akan datang, meskipun ia bersama semua orang percaya masih berada di tengah-tengah penderitaan. ${ }^{14}$ Kata yakin dalam ayat ini tidak berarti beriman, karena beberapa terjemahan menerjemahkan bukan believe, tetapi reckon (berharap, menganggap), dalam KJV diterjemahkan consider (menganggap, memperhatikan, memikirkan). ${ }^{15}$ Dengan demikian, kata

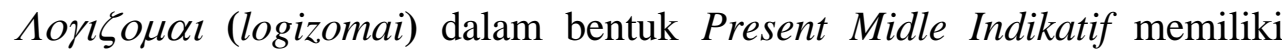
pengertian bahwa apa yang disampaikan Paulus merupakan suatu keyakinan dan kepastian bahwa orang percaya akan mengalami penderitaan, namun penderitaan itu hanya sedikit atau sebagian kecil dari kemuliaan yang akan dinyatakan.

Kata penderitaan dalam teks ini dari bahasa Yunani $\pi \alpha \theta \eta \mu \alpha \tau \alpha$ (noun, neuter, plural, Nominatif). Kata ini berasal dari kata $\pi \alpha \theta \eta \mu \alpha$ (pathema) yang berarti penderitaan, hawa nafsu. ${ }^{16}$ Hawa nafsu yang dimaksudkan di sini adalah hawa nafsu dosa atau hawa nafsu ingin berbuat dosa, yaitu dengan hidup dalam kedagingan (Rm. 7:5; Gal. 5:24). ${ }^{17}$ Dengan kata lain, penderitaan dan hawa nafsu terjadi karena dunia ini memang berdosa, penderitaan yang diderita umat manusia terjadi setelah kejatuhan manusia ke dalam dosa. Setelah dosa menguasai manusia, maka penderitaan pun timbul dalam bentuk pertentangan, kesakitan, maut, dan lain-lain (Kej. 3:15-19). ${ }^{18}$ Akibat dari hawa nafsu dosa atau hidup dalam kedagingan adalah penderitaan. Dengan demikian, penderitaan yang dimaksud dalam bagian ini adalah penderitaan akibat dosa, dalam arti lain penderitaan itu pasti ada dalam dunia sejak manusia jatuh dalam dosa. Bentuk penderitaan itu bisa berupa kesusahan, kesakitan, pertentangan dan juga hawa nafsu dosa. Hal ini menunjukkan, ada keterkaitan antara hawa nafsu dan penderitaan karena akibat dari hawa nafsu akan menimbulkan penderitaan. Tetapi penderitaan mempunyai makna baru bagi orang-orang

\footnotetext{
${ }^{13}$ Ibid., 488

${ }^{14}$ Van Den End, Surat Roma, (Jakarta: BPK Gunung Mulia, 2003), 435

${ }^{15}$ Denny Teguh Sutandio, Hidup oleh Roh dan Pengharapan Anak-anak Allah, http://www.dgip-go.id/ebscript/publicportal.cgi

${ }^{16}$ Hasan Sutanto, Perjanjian Baru Interlinear Yunani-Indonesia Jilid II, (Jakarta: Lembaga Alkitab Indonesia, 2003), 599

${ }_{17}$ Van Den End, Surat Roma..., 351

18 J. D Douglas, Ensiklopedi Alkitab Masa Kini, Vol I, (Jakarta: Yayasan Komunikasi Bina Kasih/OMF, 1995), 245
} 
percaya yang menjadi anggota tubuh Kristus. Karena mereka turut menderita dalam penderitaan Kristus (2 Kor. 1:5; Mrk. 10:39; Rm. 8:17), dan menganggap dirinya wajib menanggung penderitaan atau terpanggil kepada penderitaan (Fil. 1:29; 1 Pet. 4:1-2). Apa pun bentuk penderitaan orang Kristen, dianggap sebagai salib yang wajib dipikul dalam rangka mengikuti Yesus di jalan salib-Nya (Mat. 16:24; Rm. 8:28-29). ${ }^{19}$

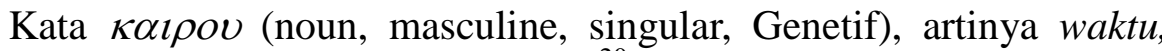
zaman, waktu yang tepat, kesempatan. ${ }^{20}$ Bentuk Genetif menunjukkan bahwa waktu ini adalah milik Tuhan. Yang dimaksudkan ialah zaman sejak kedatangan pertama Kristus sampai kedatangan-Nya kembali. ${ }^{21}$ Berkaitan dengan kata ini Dunn menjelaskan bahwa kata ini menunjukkan waktu antara kebangkitan Kristus dan kedatangan-Nya kembali. Dan ini mempunyai makna penting bagi orang percaya karena orang percaya harus melewati waktu yang jahat ini untuk menuju waktu kedatangan-Nya kembali. $^{22}$ Pemikiran Yahudi membagi waktu ke dalam dua bagian, yakni: masa sekarang dan masa yang akan datang. Masa sekarang ini semuanya jahat, diwarnai oleh dosa, kematian dan kebinasaan. Suatu ketika akan datang hari Tuhan, yaitu hari penghakiman, ketika dunia akan digoncangkan sampai ke dasarnya; tetapi sesudah itu akan datang suatu dunia baru. Ketika Paulus menggambarkan ini, ia memakai pengertian yang setiap orang Yahudi sudah mengenal dan mengerti. Ia berbicara tentang masa sekarang dan tentang kemuliaan yang akan dinyatakan. ${ }^{23}$

Kata akan dalam bahasa Yunani dipakai kata $\mu \varepsilon \lambda \lambda o v \sigma \alpha v$ (verb, Present Aktif Participle, feminine, singular, Accusative). Berasal dari kata dasar $\mu \varepsilon \lambda \lambda \omega$ (mello) yang diterjemahkan bersegera, akan datang, pasti, akan, harus, menghendaki, hampir, menunda. ${ }^{24}$ Namun dalam konteks ini penulis lebih setuju jika diterjemahkan pasti segera. Bentuk Present Aktif Participle artinya bahwa hal tersebut dilakukan pada waktu yang sama dengan apa yang disebut dalam kata kerja pada induk kalimat. ${ }^{25}$ Sedangkan Greenlee menuliskan bahwa bentuk Present Aktive Participle menyatakan identitas seseorang atau sesuatu melalui suatu karakteristik sebuah tindakan atau kegiatan. ${ }^{26}$ Dengan demikian akan dalam kasus ini memiliki pengertian bahwa kemuliaan itu pasti segera dinyatakan, dan hal itu

19 J. D Douglas, Ensiklopedi Alkitab, Vol I..., 245

${ }^{20}$ Hasan Sutanto, Perjanjian Baru Interlinear Yunani-Indonesia Jilid II..., 419

21 Van Den End, Surat Roma..., 436

22 James D. G. Dunn, Word Biblical Commentary Roman 1-8, (Dalas, Texas: Word Book Publisher, 1988), 47

23 William Barclay, Pemahaman Alkitab Setiap Hari..., 165

${ }^{24}$ Hasan Sutanto, Perjanjian Baru Interlinear ....., 507

25 Olla Tulluan, Bahasa Yunani I, (Batu: Departemen Literatur YPPII, 2002), 92

26 J. Harold Greenlee, A Consice Exegetical Grammer of New Testament Greek, (Michigan: W. B. Eerdmand Publishing Company, 1979), 55 
dilakukan pada waktu yang sama dengan kemuliaan yang akan dinyatakan. Inilah yang dinantikan setiap orang percaya yaitu kemuliaan. Kata kemuliaan dalam bahasa Yunani dipakai kata $\delta o \chi \alpha v$ (noun, feminine, singular, Accusative). Kata ini berasal dari kata dasar $\delta o \chi \alpha$ (doksa) yang diartikan kemuliaan, kemegahan, cahaya, hadirat Allah, surga (1 Tim. 3:16), makhluk sorgawi yang mulia (2 Pet. 2:10). ${ }^{27}$ Sutanto menambahkan bahwa kata ini dipakai 166 kali dalam Perjanjian Baru yang diartikan juga makhluk supranatural, kebanggaan, kebesaran, kehormatan, keindahan, ketenaran, pujian, yang mulia. ${ }^{28}$

Berkaitan dengan hal ini Douglas menuliskan bahwa kata kemuliaan mengacu pada cahaya terang yang mengelilingi Tuhan, bahkan pada hakikatnya Tuhan sendiri. Kata ini juga mengacu pada kehormatan manusia (Mat. 4:8; 6:9), tetapi penggunaannya yang utama adalah untuk menggambarkan penyataan sifat dan kehadiran Allah dalam diri dan pekerjaan Yesus Kristus. Ia adalah cahaya kemuliaan Allah (Ibr. 1:3). Dalam bahasa Yunani, kata doxa berarti pendapat atau reputasi (nama), pendapat mengenai seseorang, nama baik, kemuliaan. Dalam kosakata Yunani Perjanjian Baru doxa menjadi terjemahan Ibrani kabod, yang menunjuk kepada kehormatan dan kemuliaan manusia atau Allah (Kel. 24:16; Maz. 97:6; 1 Raj. 8:11). ${ }^{29}$ Selanjutnya End menambahkan:

Kemuliaan pertama-tama dimiliki oleh Tuhan. Istilah dalam bahasa Ibrani qabod dalam Perjanjian Lama yang diartikan cahaya terang yang mengelilingi Tuhan bilamana Tuhan menyatakan diri-Nya. Tetapi Tuhan telah menciptakan manusia menurut gambar dan rupa-Nya, sehingga manusia pun mendapat bagian dalam kemuliaan itu. Tentu kemuliaan itu menjadi kehormatan baginya. Dalam Mazmur 8:6 terdapat pasangan kata yang sama yaitu kemuliaan dan kehormatan. Maka kemuliaan itu menandakan hubungan yang sempurna antara manusia dengan Tuhan. ${ }^{30}$

Yang menjadi puncak dari semuanya ini ialah bahwa kemuliaan itu akan dinyatakan. Kata dinyatakan dalam bahasa Yunani dipakai $\alpha \pi о \kappa \alpha \lambda \nu \phi \theta \eta v \alpha \imath$ (verb, Aorist Passive Infinitive) berasal dari kata dasar $\alpha \pi о \kappa \alpha \lambda \nu \pi \tau \omega$ (apokalupto) yang diartikan membuka (rahasia),

27 Barclay M, Newman Jr, Kamus Yunani-Indonesia, (Jakarta: BPK Gunung Mulia, 2002), 43

28 Hasan Sutanto, Perjanjian Baru Interlinear Yunani-Indonesia Jilid II..., 221

29 J. D Douglas, Ensiklopedi Alkitab Masa Kini, Vol II..., 98

${ }^{30}$ Van Den End, Surat Roma..., 107-108 
mewahyukan, menyatakan. ${ }^{31}$ Bentuk Aorist Passive Infinitive dipakai untuk menyatakan suatu perbuatan yang hanya satu kali saja. ${ }^{32}$ Dalam arti bahwa kemuliaan itu telah Tuhan nyatakan. Bentuk pasif menunjukkan bahwa tidak ada andil manusia didalamnya.

Berkaitan dengan itu End menjelaskan bahwa semua manusia telah berbuat dosa dan telah kehilangan kemuliaan Allah (Rm. 3:23), tetapi orang percaya akan menerimanya kembali (Rm. 5:2; 8:30; 1 Kor. 15:40-43; 1 Tes. 2:12). 33 Dalam ayat ini tidak dikatakan "dianugerahkan kepada kita" tetapi "dinyatakan kepada kita." Kata dinyatakan yang dipilih karena kemuliaan itu memang sudah ada, tetapi masih tersembunyi. ${ }^{34}$ Dan kemuliaan itu akan dinyatakan kembali pada kedatangan Yesus yang kedua.

Dengan demikian, yang dimaksud Paulus dalam bagian ini adalah keyakinan kita bahwa penderitaan sekarang tidak sebanding dengan kemuliaan yang akan datang yang akan dinyatakan kepada kita orang yang percaya kepada-Nya. Jadi penderitaan yang kita tanggung sebagai pengikut Kristus menunjukkan keikutsertaan kita dalam penderitaan Kristus, dan dapat disebut juga "menggenapkan apa yang belum tercakup dalam penderitaan Kristus" (Kol. 1:24), supaya kita dapat bersekutu dengan Kristus dalam penderitaan-Nya. Kesukaran yang terjadi saat ini akan dibayar dengan sukacita di masa yang akan datang. "Sebab penderitaan ringan yang sekarang ini, mengerjakan bagi kami kemuliaan kekal yang melebihi segala-galanya, jauh lebih besar dari pada penderitaan kami" (2 Kor 4:17).

\section{$\underline{\text { Penderitaan yang Mengacu pada Keadaan Ciptaan (ay 19-22) }}$}

Ayat 19 dimulai dengan kata $\gamma \alpha \rho$ yang diartikan sebab. Kata ini tidak menunjukkan hubungan sebab akibat, tetapi kata ini mengawali penjelasan ayat terdahulu. Ayat 19 menjelaskan ayat 18, tetapi pada gilirannya memerlukan penjelasan yang diberikan dalam ayat 20 dan $21 .{ }^{35}$ Kata rindu dari kata $\alpha \pi о \kappa \alpha \rho \alpha \delta o \kappa \imath \alpha$ (noun, feminine, singular, Nominative) yang diartikan kerinduan. Kata apokaradokia hanya dipakai dua kali dalam Perjanjian Baru yaitu dalam Roma 8:19 dan Filipi 1:20. Kata ini secara harafiah diartikan memanjangkan leher, mengintai dengan leher yang diulurkan, menantikan dengan tegang-tegang, merindukan. ${ }^{36}$ Kata ini

\footnotetext{
31 Barclay M, Newman Jr, Kamus Yunani-Indonesia..., 19

32 Olla Tuluan, Bahasa Yunani I..., 74

33 Van Den End, Surat Roma..., 436

34 Ibid.

35 Ibid., 437

36 Van Den End, Surat Roma...,
} 
menggambarkan sikap manusia yang mengamati cakrawala dengan kepala dicondongkan ke depan, mengawasi dengan penuh perhatian ke tempat yang jauh untuk melihat tanda-tanda pertama datangnya fajar kemuliaan. ${ }^{37}$ Dengan demikian, kata ini menunjukkan ada kerinduan yang sangat (LAI: sangat rindu), dalam menantikan hari penyataan itu.

Kata makhluk dalam ayat 19 dipakai kata $\kappa \tau \imath \sigma \varepsilon \omega \varphi$ (noun, feminin, singular, Genetive), berasal dari kara dasar $\kappa \tau \imath \sigma \iota \varphi$ (ktisis) yang diartikan makhluk, penciptaan, ciptaan, dunia, lembaga, kekuasaan. ${ }^{38}$ Kata ini dipakai 19 kali dalam Perjanjian Baru. Namun dalam konteks ini lebih tepat jika diterjemahkan makhluk atau ciptaan. Berkaitan dengan kata ini, End menjelaskan:

Sejak zaman gereja lama para penafsir surat Roma berbeda pendapat mengenai isi istilah 'makhluk'. Seluruh ciptaan, termasuk malaikat dan umat manusia? Malaikat-malaikat? Seluruh umat manusia? Orang tidak percaya? Ciptaan dalam arti binatang, tanam-tanaman, dan alam tak bernyawa? Berdasarkan ayat 23 , orang percaya tidak termasuk. Kata-kata 'bukan oleh kehendak-Nya sendiri' (ay. 20) mengisyaratkan umat manusia di sini pada umumnya tidak tercantum dalam ktisis itu (Rm 5:12). Sebab umat manusia ditaklukkan kepada kesia-siaan karena pilihan salahnya sendiri. Maka, sama seperti dalam Roma 1:20+25, ktisis di sini berarti binatang, tanam-tanaman, alam tak bernyawa. Makhluk yang disebut dalam ayat 19 ini adalah makhluk Allah, yang karena itu pernah mengenal hubungan akrab dengan Dia. Tetapi hubungan itu putus, seluruh makhluk ikut terseret ketika manusia jatuh ke dalam dosa (Kej. 3:17). ${ }^{39}$

Senada dengan kalimat di atas Hagelberg menambahkan bahwa yang dimaksud dengan makhluk adalah seluruh ciptaan Allah, kecuali manusia. ${ }^{40}$ Dengan demikian kata makhluk (kecuali ayat 22) mengacu kepada seluruh ciptaan Allah yang lebih rendah dari manusia. ${ }^{41}$

Selanjutnya kata menantikan dari kata $\alpha \pi \varepsilon \kappa \delta \varepsilon \xi \xi \varepsilon \tau \alpha$ l (third person, singular, Present Midle Indicative). Kata ini barasal dari kata dasar $\alpha \pi \varepsilon \kappa \delta \varepsilon \xi o \mu \alpha \imath$ (apekdekhomai) yang diterjemahkan menanti, menantikan dengan sungguh-sungguh. ${ }^{42}$ Kata ini berasal dari preposisi apo yang

\footnotetext{
37 William Barclay, Pemahaman Alkitab Setiap Hari..., 168

${ }^{38}$ Hasan Sutanto, Perjanjian Baru Interlinear Yunani-Indonesia Jilid II..., 466

39 Van Den End, Surat Roma..., 437

40 Dave Hagelberg, Tafsiran Roma, (Bandung: Yayasan Kalam Hidup, 1998), 157

${ }^{41}$ Charles F. Pfeiffer and Everett F. Harrison, Tafsiran Alkitab Wycliffe..., 559

${ }^{42}$ Hasan Sutanto, Perjanjian Baru Interlinear Yunani-Indonesia Jilid II..., 92
} 
memiliki pengertian sungguh-sungguh, tertuju kepada, sedang asyik mengusahakan. Dan kata kerja ekdechomai memiliki pengertian mencari, mengharapkan, menantikan. ${ }^{43}$ Kata menantikan merupakan suatu ekspresi orang percaya yang harus memiliki kesungguhan dalam menantikan penyataan-Nya yang di dalamnya terdapat dua unsur yaitu pengharapan

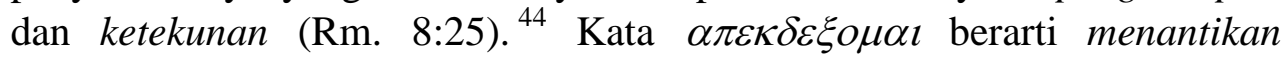
dengan sungguh-sungguh dengan hati yang tertuju kepada apa yang dinantikan.

Kata $\gamma \alpha \rho$ dalam ayat 20 menunjukkan adanya hubungan sebab akibat, yaitu antara ayat 20 dan 21 dengan ayat $19 .{ }^{45}$ Kata ditaklukkan dalam ayat 20 dalam bahasa Yunani dipakai kata $v \pi \varepsilon \tau \alpha \gamma \eta$ (third person, singular, Aorist Passive Indikative). Berasal dari kata dasar $v \pi o \tau \alpha \sigma \sigma \omega$ (hupotasso) yang diterjemahkan manaklukkan, menundukkan, tunduk. ${ }^{46}$ Kata ditaklukkan dan menaklukkan dalam ayat ini memakai bentuk Aorist sehingga dapat dikaitkan dengan peristiwa tertentu di masa lampau. ${ }^{47} \mathrm{Hal}$ ini mengacu pada Kejadian 3:15 dan Roma 16:20, sebagaimana kejatuhan manusia telah mandatangkan malapetaka atas seluruh alam semesta, begitu juga pemulihan kedudukan manusia akan membawa pemulihan kemuliaan alam semesta. ${ }^{48}$ Kata $v \pi o \tau \alpha \sigma \sigma \omega$ (hupotasso) berasal dari preposisi hupo dan tasso, yang diartikan menaklukkan, menempatkan diri dalam keadaan yang rendah.

Kata kesia-siaan dari kata $\mu \alpha \tau \alpha \iota \sigma \eta \tau \imath$ (feminine, singular, Dative) yang berasal dari kata dasar $\mu \alpha \tau \alpha \iota$ in $\varphi$ (mataiotes) yang diterjemahkan kesia-siaan, kehampaan. ${ }^{50}$ Akar kata Yunani dari kata ini adalah mataios, secara kiasan kata ini berkaitan dengan ilmu sihir. ${ }^{51}$ Tetapi sebaiknya menafsirkan kata kesia-siaan dengan melihat Kejadian 3:17-19 dan Roma 1:18-32. Allah telah menciptakan alam demi kemuliaan-Nya sendiri. Tetapi manusia, yang telah diangkat menjadi penguasa alam itu, jatuh ke dalam dosa sehingga kehidupannya menjadi kacau dan sia-sia. Berarti tidak memenuhi lagi tujuannya, yakni memuliakan Tuhan. Maka seluruh lingkungan kekuasaannya yaitu alam ikut kena kekacauan dan kesia-siaan,

43 Spiros Zodhiates, The Complete Word Study Dictionary of New Testament, (Chattanooga: AMG Publisher, 1993), 210

44 Ibid

45 Van Den End, Surat Roma..., 438

46 Barclay M, Newman Jr, Kamus Yunani-Indonesia..., 180

47 Van Den End, Surat Roma..., 438

48 Ibid., 440

49 Spiros Zodhiates, The Complete Word Study Dictionary of New Testament..., 1427

50 Barclay M, Newman Jr, Kamus Yunani-Indonesia..., 103

51 Van Den End, Surat Roma..., 439 
sehingga tidak lagi dapat menunaikan tugasnya yang agung. ${ }^{52}$

Kata kehendak dari kata $\varepsilon \kappa o v \sigma \alpha$ (Adjective feminine, singular, Nominative) berasal dari kata dasar $\varepsilon \kappa \omega v$ (hekon) yang diterjemahkan yang rela atau dengan rela. ${ }^{53}$ Sedangkan Newman menerjemahkan menurut kehendaknya sendiri. ${ }^{54}$ Kata ini didahului dengan kata ov $\xi$ (ouk) yang diterjemahkan tidak, bukan, jangan. Namun dalam konteks ini lebih tepat diterjemahkan bukan, sesuai dengan terjemahan LAI. Kata ini mengandung arti bukan karena kesalahannya sendiri. Makhluk ikut bersalah ketika Adam mendurhaka terhadap Tuhan. ${ }^{55}$ Dengan demikian, kata ini memiliki arti bahwa ciptaan ini ditaklukkan pada kesia-siaan bukan karena kehendak mereka sendiri atau bukan karena kesalahan mereka melainkan karena kehendak Tuhan.

Kemudian di akhir ayat 20 ini ada kata menaklukkannya, dari kata

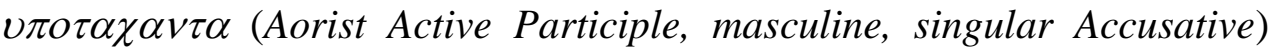
yang dari kata dasar $v \pi o \tau \alpha \sigma \sigma \omega$ (hupotasso) yang diterjemahkan menaklukkan, menundukkan, mematuhi, takluk, menerima perintah dari, mengambil tempat rendah (1 Kor. 14:34). ${ }^{56}$ Namun dalam konteks ayat ini lebih tepat jika diterjemahkan telah menundukkan.

Kata ini didahului dengan kata Tov yang diterjemahkan Dia yang. ${ }^{57}$ Karena kata ini dalam bentuk Pasive menimbulkan dugaan bahwa yang menaklukkan alam itu adalah Allah sendiri (Kej. 3:17; Rm. 1:21; 3:27). Dengan demikian, kesia-siaan atau kerusakan dunia ini diizinkan oleh kehendak Allah. Allah mengizinkan dosa terjadi di dalam dunia, tetapi ingat, bukan Allah penyebab dosa. Allah ingin menunjukkan betapa rapuh dan rusaknya manusia tanpa Allah. ${ }^{58}$ Badai taufan, angin ribut, gempa bumi, kekeringan, banjir merupakan sedikit bukti dari ketidakseimbangan alam. Paulus mengatakan bahwa alam sampai pada keadaan ini karena Allah. ${ }^{59}$ Tetapi Allah menaklukkan ciptaan pada kesia-siaan dalam pengharapan. ${ }^{60}$

Kata pengharapan dalam ayat 21 dipakai kata $\varepsilon \lambda \pi \imath \delta \imath$ (feminine, singular, Dative) dari kata dasar $\varepsilon \lambda \pi \imath \varphi$ (elpis) yang diterjemahkan harapan berarti suatu keyakinan, apa yang diharapkan, atau alasan untuk berharap. ${ }^{61}$ Pengharapan yang dimaksud di sini adalah pengharapan yang

\footnotetext{
52 Dave Hagelberg, Tafsiran Roma..., 157

53 Hasan Sutanto, Perjanjian Baru Interlinear Yunani-Indonesia Jilid II..., 266

54 Barclay M, Newman Jr, Kamus Yunani-Indonesia..., 52

55 Van Den End, Surat Roma..., 440

56 Barclay M, Newman Jr, Kamus Yunani-Indonesia..., 180

57 Hasan Sutanto, Perjanjian Baru Interlinear Yunani-Indonesia Jilid I..., 843

58 Denny Teguh Sutandio, Hidup Oleh Roh dan Pengharapan Anak-anak Allah

59 Charles F. Pfeffer and Everett F. Harrison, Tafsiran Alkitab Wycliffe..., 559

${ }^{60}$ Dave Hagelberg, Tafsiran Roma..., 157

61 Hasan Sutanto, Perjanjian Baru Interlinear Yunani-Indonesia Jilid II..., 271
} 
pasti akan suatu saat ketika kegagalan atau kesia-siaan akan ditiadakan. ${ }^{62}$ Dengan demikian pengharapan di sini berarti harapan adanya suatu keyakinan dan kepastian bahwa orang percaya akan dibebaskan atau dimerdekakan dari kesia-siaan.

Kata dimerdekakan dipakai kata $\varepsilon \lambda \varepsilon v \theta \varepsilon \rho \omega \theta \eta \sigma \varepsilon \tau \alpha \imath$ (third person, singular, Future Passive Indicative) yang berasal dari kata dasar $\varepsilon \lambda \varepsilon v \theta \varepsilon \rho o \omega$ (eleutheroo) yang diterjemahkan membebaskan, memerdekakan. ${ }^{63}$ Bentuk Future Passive Indicative menunjukkan apa yang menyangkut masa depan. ${ }^{64}$ Dengan demikian kata ini berarti bahwa ada waktunya orang percaya akan dibebaskan atau dimerdekakan dari perbudakan kebinasaan. Dengan kata lain, kata ini menunjukkan adanya suatu proses pembebasan dari perbudakan.

Kata perbudakan dari kata $\delta o v \lambda \varepsilon \iota \alpha \varphi$ (feminine, singular, Genetive) berasal dari kata dasar $\delta o v \lambda \varepsilon i \alpha$ (douleia) yang diterjemahkan perhambaan, perbudakan. ${ }^{65}$ Sedangkan kata perbudakan dari kata $\phi \theta 0 \rho \alpha \varphi$ (noun, feminim, singular, Genetive) yang berasal dari kata dasar $\phi \theta o \rho \alpha \quad$ (phthora) yang diterjemahkan kebinasaan, kefanaan, kerusakan moral, rusak, pembinasaan. ${ }^{66}$ Istilah ini menunjuk pada kenyataan bahwa segala sesuatu yang kelihatan di dunia ini bersifat fana, dan akan busuk atau binasa. Hal ini berkaitan erat dengan kata kesia-siaan yang disebut dalam ayat $20 .^{67}$ Dengan demikian, arti kedua kata ini adalah perbudakan yang menghasilkan kebinasaan, kerusakan moral, dan kefanaan. Namun Allah berjanji bahwa setiap ciptaan yang telah diperbudak oleh kebinasaan dan kehancuran, suatu saat akan dibebaskan dari keadaan tersebut dan masuk ke dalam kemerdekaan kemuliaan anak-anak Allah. ${ }^{68}$

Kata kemerdekaan dari kata $\varepsilon \lambda \varepsilon v \theta \varepsilon \rho \imath \alpha v$ (eleutherian), kata dasarnya $\varepsilon \lambda \varepsilon v \theta \varepsilon \rho i \alpha$ (eleutheria) yang diterjemahkan kebebasan, kemerdekaan. ${ }^{69}$ Kata kemerdekaan yang dimaksud di sini menunjukkan hasil dari proses pembebasan (dimerdekakan) yang sudah dijelaskan di atas. Hasil pembebasan itu sendiri adalah kemerdekaan, yaitu kemerdekan yang menghasilkan kehormatan atau kemuliaan. Kata kemuliaan merupakan kata yang sama yang dipakai dalam ayat 18, namun dalam ayat ini lebih tepat jika diterjemahkan kehormatan. Dengan demikian, kemerdekaan ini akan menghasilkan kehormatan anak-anak Allah.

62 Charles F. Pfeffer and Everett F. Harrison, Tafsiran Alkitab Wycliffe..., 559

${ }^{63}$ Hasan Sutanto, Perjanjian Baru Interlinear Yunani-Indonesia Jilid II..., 269

${ }^{64}$ Olla Tuluan, Bahasa Yunani I..., 40

65 Barclay M, Newman Jr, Kamus Yunani-Indonesia..., 44

66 Hasan Sutanto, Perjanjian Baru Interlinear Yunani-Indonesia Jilid II..., 792

${ }^{67}$ Dave Hagelberg, Tafsiran Roma..., 157

${ }^{68}$ Charles F. Pfeffer and Everett F. Harrison, Tafsiran Alkitab Wycliffe..., 559

69 Hasan Sutanto, Perjanjian Baru Interlinear Yunani-Indonesia Jilid II..., 269 
Kata anak-anak, dalam teks Yunani $\tau \varepsilon \kappa v \omega v$ yang diterjemahkan anak, keturunan, penduduk suatu kota. ${ }^{70}$ Kata ini berbeda dengan kata $v \imath o \varphi$ yang dipakai dalam ayat 19. Kata ini menjelaskan bahwa semua yang lahir dari atas yaitu semua yang disebut anak-anak Allah akan berperan serta dalam kemerdekaan kemuliaan itu. Tetapi dalam ayat 19 ia memakai kata huios karena yang dinantikan oleh ciptaan Allah adalah penguasa baru, mereka yang akan memerintah bersama Tuhan Yesus, dan kata ini disamakan dengan kata ahli waris Kristus dalam ayat $17 .^{71}$ Kemudian diikuti dengan kata $\theta \varepsilon o v$ (noun, masculine, singular, Genetive) yang diterjemahkan Allah, sesuai dengan kehendak Allah atau menurut persamaan Allah (Kis. 19:37). ${ }^{72}$ Genetive di sini menyatakan milik. Dalam arti anak-anak itu adalah milik kepunyaan Allah. Dengan demikian, kemerdekaan merupakan hasil kemuliaan anak-anak Allah. Artinya penyingkapan kemuliaan itu pada akhir zaman akan memerdekakan (membebaskan) ciptaan dari keterikatan pada kebinasaan. Pada saat manusia jatuh ke dalam dosa, alam kehilangan kemuliaan, dan menjadi kacau balau. Tetapi pada zaman akhir, kemuliaan anak-anak Allah akan dipulihkan dan dengan demikian makhluk-makhluk lainnya akan kembali menjadi amat baik. ${ }^{73}$

Ayat 22 ini merupakan ringkasan dari ayat 20-21 dan dengan demikian ikut menjelaskan ayat 19. Ayat ini dimulai dengan kata sebab kita tahu. Kata ini menunjukkan kenyataan yang umum diketahui dan diakui oleh orang Kristen ( $\mathrm{Rm} 2: 2 ; 7: 4)$. Yang dimaksud dengan kata ini adalah segala makhluk sama-sama mengeluh dan sama-sama merasa sakit bersalin. Istilah sama-sama itu tidak berarti bersama-sama anak-anak Allah. ${ }^{74}$ Kata sama-sama mengeluh dalam teks Yunani $\sigma v \sigma \tau \varepsilon v \alpha \zeta \varepsilon l$ (verb, third person, singular, Present Active Indicative). Kata ini berasal dari kata dasar $\sigma v \sigma \tau \varepsilon v \alpha \zeta \omega$ (sustenazo) yang diterjemahkan mengeluh bersama, merintih bersama. ${ }^{75}$ Kata ini hanya dipakai satu kali dalam Perjanjian Baru yaitu dalam ayat ini. Bentuk Present Active Indicative menunjukkan waktu 'masa kini', dan juga menyatakan sesuatu yang berlangsung terus-menerus atau berulang kali. ${ }^{76}$ Kata ini memiliki arti mengerang (merasa sakit dengan hebat) atau keluh kesah secara berkepanjangan yang dirasakan oleh ciptaan. ${ }^{77}$ Dengan demikian keadaan ini (mengeluh) akan terjadi pada

\footnotetext{
${ }^{70}$ Hasan Sutanto, Perjanjian Baru Interlinear Yunani-Indonesia Jilid II..., 748

${ }^{71}$ Dave Hagelberg, Tafsiran Roma..., 157

72 Barclay M, Newman Jr, Kamus Yunani-Indonesia..., 77

73 Van Den End, Surat Roma..., 441

74 Ibid., 443

75 Hasan Sutanto, Perjanjian Baru Interlinear Yunani-Indonesia Jilid II..., 738

${ }^{76}$ Olla Tuluan, Bahasa Yunani I..., 34

77 Spiros Zodhiates, The Complete Word Study Dictionary of New Testament...,
} 
masa sekarang ini, dan akan berlangsung terus-menerus sampai kedatangan-Nya yang kedua. Kemudian dilanjutkan dengan kata sama-sama merasa sakit bersalin, yang dalam teks Yunani $\sigma v v \omega \delta \imath v \varepsilon \imath$ (verb, third person, singular, Present Active Indicative) berasal dari kata dasar $\sigma v v \omega \delta \imath v \omega$ (sunodino) yang diterjemahkan merasa nyeri bersama (seperti wanita sedang melahirkan) ${ }^{78}$ merasa sakit bersalin bersama, atau sangat menderita bersama. ${ }^{79}$ Kata ini juga hanya dipakai sekali dalam Perjanjian Baru yaitu dalam ayat ini.

Cranfield menjelaskan bahwa rabi-rabi Israel memakai istilah sakit bersalin Mesias yang menunjuk bukan saja pada penderitaan Mesias, tetapi juga penderitaan di dunia yang mengawali kedatangan Mesias, rupanya gambaran tersebut berasal dari ayat-ayat Perjanjian Lama (Yes. 26:17; 66:8; Yer. 4:31; Hos. 13:13; Mi. 4:9) dan dikembangkan dalam Perjanjian Baru (Mrk. 13:9; Yoh. 16:21; 1 Tes. 5:3). ${ }^{80}$ Kata ini juga berarti bersama-sama merasa sakit seperti seorang wanita yang akan melahirkan, merasa sakit bersama-sama. Secara figuratif arti kata bersama-sama merasakan kesakitan, yang dalam satu kesadaran sebagai suatu ciptaan. ${ }^{81}$ Dengan demikian, arti kata ini dalam Present Active Indicative adalah menunjukkan kesakitan, penderitaan (seperti orang yang akan melahirkan) yang dialami pada masa kini dan akan berlangsung secara terus-menerus sampai Tuhan menyatakan diri-Nya.

Dengan demikian, bagian kedua ini meneguhkan pengharapan yang telah dituliskan dalam ayat 18 yaitu bahwa kemuliaan yang akan datang itu akan lebih kuat kalau orang percaya memperhatikan makhluk lainnya. Allah telah mengaitkan keadaan mereka dengan keadaan manusia, sehingga mereka ikut menanggung akibat kesalahan manusia. Tetapi makhluk lain itu turut menikmati pula keselamatan dan kemuliaan yang dijanjikan kepada manusia.

\section{Orang Percaya Memiliki Keselamatan Berupa Pengharapan (ay 23-25)}

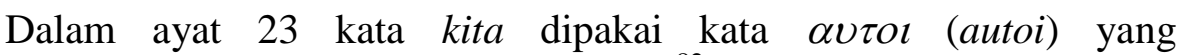
diterjemahkan diri sendiri, atau kita sendiri. ${ }^{82}$ Kata ini didahului dengan

1349

78 Barclay M, Newman Jr, Kamus Yunani-Indonesia..., 166

79 Hasan Sutanto, Perjanjian Baru Interlinear Yunani-Indonesia Jilid II..., 737

${ }^{80}$ C. E. B. Cranfield, A Critical and Exegetical Commentary on The Epistle to the Romans, (Edinburgh: The International Commentary, Clark Limited, 1975), 416

${ }^{81}$ Spiros Zodhiates, The Complete Word Study Dictionary of New Testament..., 1347

82 Ibid., 129 
kalimat dan bukan mereka saja, ini menunjukkan kesejajaran dengan ayat sebelumnya, bahkan suatu peningkatan. Peningkatan ini diperkuat lagi dengan pengulangan kata kita dengan tambahan kata sendiri: bahkan kita sendiri. Kita yang dimaksudkan di sini adalah kita yang mempunyai karunia sulung Roh $^{83}$ Kata karunia sulung dipakai kata $\alpha \pi \alpha \rho \xi \eta \nu$ (noun, feminine, singular, Accusative) dari kata dasar $\alpha \pi \alpha \rho \xi \eta$ (aparkhe) yang diterjemahkan sulung (istilah Yahudi untuk bagian yang pertama termasuk hewan yang dikhususkan bagi Allah sebelum sisanya dapat digunakan), ${ }^{84}$ buah sulung berarti bagian awal atau yang pertama. ${ }^{85}$ Kata ini dipakai sembilan kali dalam Perjanjian Baru (Rm. 11:16; 16:5; 1 Kor. 15:20,23; 16:15; Yak. 1:18 dan Why. 14:4). Secara harafiah istilah ini menunjuk pada hasil pertama dari setiap tuaian. Secara kiasan istilah ini menunjuk antara lain pada hasil pertama dari suatu pelayanan orang (Rm. 16:5) atau hasil pertama dari pelayanan Roh Kudus (Rm. 8:23). ${ }^{86}$ Namun dalam ayat ini karunia sulung tidak mengacu pada persembahan manusia kepada Allah, tetapi pada pemberian Allah kepada manusia, yaitu kehadiran Roh Kudus, sebagai jaminan pemberian lebih besar yang akan diterima di masa depan (2 Kor 5:5). ${ }^{87}$

Zodhiates menjelaskan bahwa istilah ini merupakan pemberian Allah yaitu karunia Roh yang Kudus sebagai suatu pendahuluan atau jaminan sebagai warisan orang percaya yang bersifat kekal (Rm. 8:23; Ef 1:14; Ibr. $6: 5){ }^{88}$ Kata karunia sulung dilanjutkan dengan kata Roh yang dalam teks Yunani $\pi v \varepsilon v \mu \alpha \tau o \varphi$ (pneumatos), dari akar kata $\pi v \varepsilon v \mu \alpha$ (pneuma) yang diterjemahkan roh, napas, angin, Roh. ${ }^{89}$ Berkenaan dengan kata ini Barclay menjelaskan:

Kata ini kurang lebih 20 kali dipakai dalam pasal ini. Kata ini mempunyai latar belakang yang jelas dalam Perjanjian Lama. Dalam bahasa Ibraninya dipakai kara Ruakh, dan kata ini mempunyai dua arti dasar: (a) Tidak hanya berarti Roh, tetapi juga angin. Dan di dalamnya ada pengertian tentang kuasa, yaitu kuasa seperti angin yang dasyat. (b) Dalam Perjanjian Lama, kata ini selalu dipakai dalam pengertian sesuatu yang melebihi manusia. Bagi Paulus, Roh menyatakan suatu kuasa Ilahi. ${ }^{90}$

\footnotetext{
${ }^{83}$ Van Den End, Surat Roma..., 444

${ }^{84}$ Barclay M, Newman Jr, Kamus Yunani-Indonesia..., 16

85 Hasan Sutanto, Perjanjian Baru Interlinear Yunani-Indonesia Jilid II..., 91

86 Dave Hagelberg, Tafsiran Roma..., 158

87 Van Den End, Surat Roma..., 445

${ }^{88}$ Spiros Zodhiates, The Complete Word Study Dictionary of New Testament..., 206

89 Hasan Sutanto, Perjanjian Baru Interlinear Yunani-Indonesia Jilid II..., 651

90 William Barclay, Pemahaman Alkitab Setiap Hari..., 156
} 
Selanjutnya berkenaan dengan kata ini End juga menjelaskan:

Tambahan 'Roh' di belakang 'karunia sulung' dapat ditafsirkan dengan tiga cara. (a) Karunia sulung itu merupakan bagian pertama dari Roh dan karya-Nya; di masa depan kita akan menerima Roh sepenuhnya. (b) Roh (kehadiran-Nya, karya-Nya dalam diri kita) itu sendiri merupakan pemberian pertama, yang akan disusul pemberian lain, yaitu kemuliaan (ay. 18), pembebasan tubuh (ay. 23b) di masa depan. (c) Karunia sulung adalah pemberian pertama oleh Roh; di masa depan Roh akan mengaruniakan hal-hal lain lagi kepada kita (ay 18, 23b). ${ }^{91}$

Dari segi tata bahasa, ketiga tafsiran ini dapat diterima, namun jika dilihat dari keseluruhan pasal 8 penulis lebih memilih tafsiran yang kedua karena tepat dengan konteks pasal ini. Dengan demikian karunia sulung yaitu Roh. Allah yang memberikan Roh kepada kita sebagai jaminan (2 Kor. 5:5). Dia juga yang akan memberikan berkat-berkat lain di masa depan.

Kata mengeluh dalam ayat ini dari kata $\sigma \tau \varepsilon v \alpha \zeta o \mu \varepsilon v$ (verb, first person, plural, Present Active Indicative), dari kata dasar $\sigma \tau \varepsilon v \alpha \zeta \omega$ (stenazo) yang diterjemahkan mengeluh, bernafas keras (karena simpati). ${ }^{92}$ Kata ini juga berarti situasi ketika ditekan oleh keadaan, mengerang, keluh kesah yang berkepanjangan, kesusahan, penderitaan (Rm. 8:23; 2 Kor. 5:2,4; Ibr. 13:17). ${ }^{93}$ Kata ini lebih tepat sebagai ungkapan sedih karena hidup dalam dunia yang penuh dosa. ${ }^{94}$ Penggunaan yang kedua dari kata mengeluh, tentu saja adalah secara sadar diharapkan untuk mengingat keluhan ciptaan di dalam ayat 22, namun dalam ayat 23 ini untuk menekankan keterlibatan orang percaya di dalam rasa sakit, atau penderitaan yang akan menghasilkan sesuatu yang bersifat eskatologi, ${ }^{95}$ sambil menantikan dengan sungguh-sungguh pengangkatan sebagai anak.

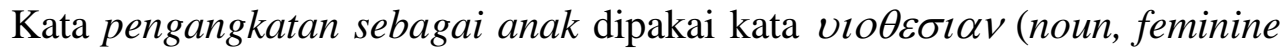

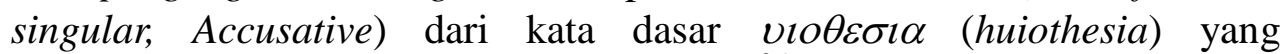
diterjemahkan pengangkatan sebagai anak. ${ }^{96}$ Paulus menggunakan istilah pengangkatan sebagai anak dalam kehidupan Romawi karena pengangkatan sebagi anak lebih serius dan lebih sulit karena adanya konsep

91 Van Den End, Surat Roma..., 445

92 Hasan Sutanto, Perjanjian Baru Interlinear Yunani-Indonesia Jilid II..., 717

93 Spiros Zodhiates, The Complete Word Study Dictionary of New Testament..., 1310

${ }^{94}$ Charles F. Pfeiffer and Everett F. Harrison, Tafsiran Alkitab Wycliffe..., 559

95 James D. G. Dunn, Word Biblical Commentary Roman 1-8..., 474

96 Hasan Sutanto, Perjanjian Baru Interlinear Yunani-Indonesia Jilid II..., 770 
patria potestas yaitu kekuasaan ayah atas keluarganya. Dalam hubungan dengan ayahnya, seorang anak laki-laki sebenarnya tidak pernah menginjak dewasa, tak peduli berapa pun umurnya, ia tetap di bawah patria potestas. Dalam pengangkatan anak, seorang harus bisa keluar dari satu patria potestas dan masuk ke bawah yang lain. ${ }^{97}$ Mengenai istilah pengangkatan sebagai anak, Barclay menjelaskan:

(a) Orang yang diangkat itu kehilangan seluruh hak di dalam keluarganya yang lama, dan mendapat hak sebagai anak yang sah dalam keluarganya yang baru. Melalui jalan sah yang sangat mengikat itu, ia mendapat seorang ayah baru. (b) Ia menjadi ahli waris atas harta ayah barunya. Walaupun sesudah itu lahir anak yang lain, hal itu tidak mempengaruhi haknya. Tidak dapat dicabut haknya untuk bersama-sama mewarisi dengan mereka. (c) Secara hukum, kehidupan yang lama dari orang yang diadopsi itu dihapuskan; misalnya, semua hutang-hutang dibatalkan. Ia dianggap sebagai orang baru yang masuk ke dalam kehidupan baru; yang lama sama sekali tidak berlaku lagi. (d) Dalam pandangan hukum, ia adalah mutlak anak dari ayah barunya. ${ }^{98}$

Dengan demikian, Paulus menggunakan gambaran ini pada pengangkatan orang percaya ke dalam keluarga Allah. Dahulu manusia berada di dalam kekuasaan mutlak dari tabiat manusia yang berdosa, tetapi karena kasih setia-Nya, Allah telah membawa orang percaya ke dalam ikatan kasih-Nya. Kehidupan lama tidak mempunyai hak lagi, Allah yang mempunyai hak mutlak. Yang lama telah dibatalkan dan hutangnya telah dihapuskan, orang percaya mulai dengan kehidupan yang baru dengan Allah dan menjadi ahli waris seluruh kekayaan-Nya. Dengan demikian pengangkatan sebagai anak di sini yang dimaksud adalah pembebasan tubuh.

Kata pembebasan diterjemahkan dari kata $\alpha \pi \delta \lambda v \tau \rho \omega \sigma \iota v \square$ (noun, feminine, singular, Accusative) dari kata dasar $\alpha \pi \circ \lambda \nu \tau \rho \omega \sigma \iota \varphi$ (apolutrosis) yang diterjemahkan pembebasan, penebusan. ${ }^{99}$ Kemudian dilanjutkan dengan kata tubuh, dari kata $\sigma \omega / \mu \alpha \tau O \varphi$ (somatos) yang diterjemahkan tubuh, jenazah, bangkai, hamba, kenyataan. ${ }^{100}$ Namun dalam konteks ini lebih tepat diterjemahkan tubuh. Yang dimaksud dengan pembebasan tubuh kita adalah kita akan dibebaskan dari kuasa dosa dan maut (1 Kor. 15:54; Fil. $3: 21) .{ }^{101}$ Berkaitan dengan ini Preiffer dan Harrison menambahkan bahwa

\footnotetext{
97 William Barclay, Pemahaman Alkitab Setiap Hari..., 161

98 Ibid., 162

99 Hasan Sutanto, Perjanjian Baru Interlinear Yunani-Indonesia Jilid II..., 104

100 Ibid., 741

101 Van Den End, Surat Roma..., 446
} 
yang dimaksud pembebasan tubuh kita adalah pembebasan dari dosa dan keterbatasan, yang tekanan-tekanannya senantiasa kita rasakan selama kita hidup di dalam tubuh yang fana ini. ${ }^{102}$

Ayat 24 langsung merumuskan pertentangan yang telah dicatat pada permulaan tafsiran ayat 23. Mengapa orang percaya masih mengeluh sambil menantikan pembebasan? Jawabnya: "Sebab kita diselamatkan dalam pengharapan" (ay. 24a). Kata kita dalam ayat ini adalah kata yang sama dengan "kita yang telah menerima buah sulung" (ay. 23). Kata diselamatkan dipakai kata $\varepsilon \sigma \omega \theta \eta \mu \varepsilon v$ (verb, first person, plural, Aorist Passive Indicative) dari kata dasar $\sigma \omega \zeta \omega$ (sozo) yang diterjemahkan menyelamatkan, membebaskan, mengamankan, melestarikan, menyembuhkan. ${ }^{103}$ Kata diselamatkan memakai bentuk Aorist yang menunjukkan peristiwa di masa lampau. ${ }^{104}$

Berkaitan dengan ini Zodhiates menjelaskan arti kata keselamatan dalam lima bagian: Pertama, kata ini biasa digunakan terutama untuk menolong orang-orang dari kesusahan atau kesulitan (Mat. 8:25; 14:20; Kis. 27:20,31). Kedua, menyembuhkan orang-orang yang sakit, menyelamatkan dari kematian dan dengan tujuan untuk menyembuhkan, menyehatkan sampai kepada pemulihan (Mat. 9:21, 22; Mrk. 5: 23). Ketiga, secara khusus berarti keselamatan dari kematian kekal, dosa, hukuman dan kesengsaraan sebagai akibat dosa. Sehingga keselamatan ini memberikan hidup kekal (Kis. 2:40; Rm. 5:9). Keempat, maksud kata kerja dasar $\sigma \omega \zeta \omega$ memiliki arti untuk menolong dari risiko, untuk melindungi, untuk melihara dalam keadaan hidup. Kata ini juga menyangkut pemeliharaan hidup, yang bersifat rohani maupun secara fisik. Kelima, berkaitan dengan keselamatan jiwa yaitu kelepasan dari kebinasaan dengan hidup melalui Kristus (Yoh. 6:56; 14:20; Rm. 16:7; Ef. 2:13). ${ }^{105}$

Kata keselamatan yang dipakai dalam ayat ini sama dengan keselamatan yang ada dalam pasal 1:16; 5:9, yaitu keselamatan dari murka Allah, ${ }^{106}$ yang diceritakan dalam pasal 1:18-32, suatu murka yang dialami zaman ini oleh setiap makhluk yang hidup dalam dunia yang berdosa ini. Orang percaya yang telah menerima buah sulung Roh akan diselamatkan dari murka Allah yang dialami oleh orang lain di muka bumi ini. ${ }^{107}$ Makna

102 Charles F. Preiffer and Everett F. Harrison, Tafsiran Alkitab Wycliffe..., 559

103 Barclay M, Newman Jr, Kamus Yunani-Indonesia..., 167

104 Olla Tuluan, Bahasa Yunani I..., 40

105 Spiros Zodhiates, The Complete Word Study Dictionary of New Testament..., $1353-1354$

${ }^{106}$ Istilah murka Allah menunjukkan murka Allah yang sedang dinyatakan atas segala kefasikkan dan kelaliman manusia dalam bentuk penyerahan pada dosa yang semakin mengerikan, dan pada murka Allah pada akhir zaman seperti yang disebut dalam Roma 2: 5 .

107 Spiros Zodhiates, The Complete Word Study Dictionary of New Testament..., 
kata ini akan bertambah jelas setelah memperhatikan bentuk kata kerja Yunani. Kata ini menjadi kita telah diselamatkan, tetapi keselamatan itu baru kita peroleh dengan cara pengharapan. ${ }^{108}$ Dengan keselamatan yang telah kita peroleh memberi kita pengharapan.

Kata pengharapan sendiri dipakai dalam teks bahasa Yunani $\varepsilon \lambda \pi \imath \delta \imath$. Kata yang sama dipakai dalam ayat 21. Dalam ayat ini kata pengharapan terdapat tiga kali. Dan satu kali memakai kata dasar $\varepsilon \lambda \pi l \zeta \omega$ (elpizo) yang diterjemahkan berharap atau mengharap. ${ }^{109}$ Kata ini dalam bentuk Dative yang menunjukkan objek tak langsung (pelengkap penyerta/penderita). ${ }^{110}$ Sehingga kata ini mengandung arti oleh, bagi/untuk, atau secara. Melihat isi ayat $24 \mathrm{~b}$ dan 25 , arti pertama dan kedua tidak mungkin, sehingga arti Dative di sini menunjukkan cara penyelamatan orang percaya. ${ }^{111}$ Kata pengharapan dipakai 13 kali dalam surat Roma. ${ }^{112}$

Hagelberg membedakan pengharapan dalam dua bagian yaitu pengharapan karena hasil penderitaan orang percaya dalam tangan Tuhan dan pengharapan karena hasil anugerah Tuhan. ${ }^{113}$ Dalam konteks ayat ini pengertian keduanya dapat diterima. Istilah pengharapan berarti antisipasi yang penuh keyakinan dari apa yang belum kita lihat. ${ }^{114}$

Dalam lingkungan orang-orang Yunani pengharapan berarti mudah-mudahan besok lebih baik daripada hari ini. Sedangkan dalam lingkungan orang-orang Yahudi istilah pengharapan menunjuk pada suatu keyakinan yang teguh mengenai masa depan yang cerah. ${ }^{115}$ Dalam konteks ini, bahkan konteks surat Roma, penulis lebih setuju arti yang bersifat Yahudi, karena arti ini lebih tepat untuk kata pengharapan itu sendiri, yaitu suatu keyakinan yang teguh mengenai masa depan yang cerah.

Berkenaan dengan hal ini Pfeiffer dan Harrison menjelaskan bahwa pengharapan ialah suatu penantian penuh keyakinan akan berkat-berkat yang dijanjikan yang sekarang belum ada atau belum tampak. Pengharapan ini bukanlah keinginan akan sesuatu yang terlalu indah yang tidak mungkin menjadi kenyataan. Berkat yang diharapkan itu (penebusan tubuh), bersifat nyata dan jelas sekalipun belum ada. ${ }^{116}$

Kemudian ayat ini diakhiri dengan kalimat bagaimana orang masih mengharapkan apa yang dilihatnya? Kata dilihatnya dari kata Yunani

160

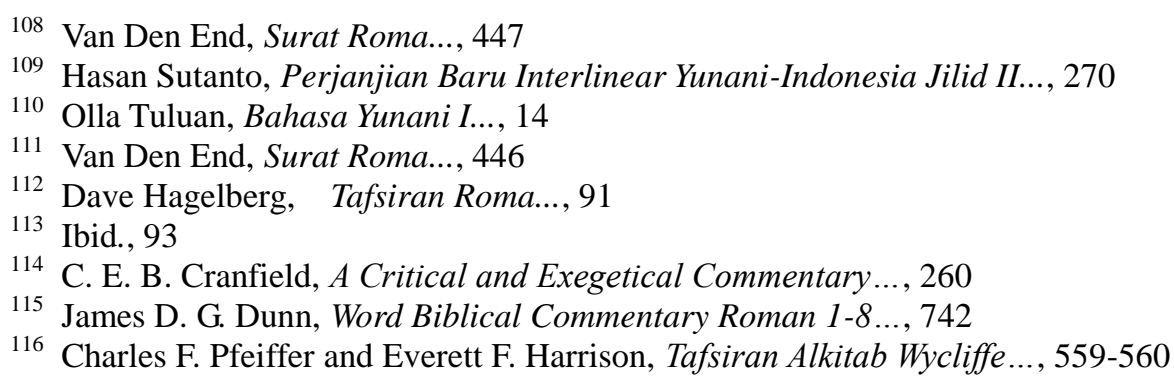


$\beta \lambda \varepsilon \pi \circ \mu \varepsilon v$ (verb, first person, plural, Present Active Indicative) dari kata dasar $\beta \lambda \varepsilon \pi \omega$ (blepo) yang diterjemahkan melihat, dapat melihat, mewaspadai, memperhatikan, merasakan, sadar, ingat, berusaha, menghadap. ${ }^{117}$ Kata melihat di sini diartikan melihat dengan mata jasmani, atau melihat hal-hal jasmani (2 Kor 4:18). Melihat dengan cara itu berbeda dengan melihat Tuhan (2 Kor. 5:7). ${ }^{118}$ Present Active Indicative menyatakan masa kini dan menyatakan sesuatu yang berlangsung secara terus-menerus atau berulang kali. ${ }^{119}$ Jadi melihat dalam bentuk Present Active Indicative menunjukkan bahwa manusia sedang dan terus-menerus melihat secara jasmani selama manusia masih ada di dalam dunia sekarang ini. Dengan demikian yang dimaksud di sini adalah bagaimana orang masih mengharapkan apa yang dilihatnya atau yang sudah kelihatan dengan mata. Maka pengharapan yang dilihat hanyalah pengharapan akan hal-hal jasmani, sedangkan pengharapan Kristen justru menyangkut kemuliaan yang belum terdapat dalam dunia ini, yaitu dunia baru yang berbeda dengan dunia ini (1 Kor. 15:40-49). Hidup orang percaya (keselamatan) belum tampak, tetapi tersembunyi bersama dengan Kristus di dalam Allah (Kol. 3:3). ${ }^{120}$

Bagian ini diakhiri dengan kalimat: "tetapi jika kita mengharapkan apa yang tidak kita lihat, kita menantikannya dengan tekun.” Kata tetapi dalam ayat ini tidak menunjukkan pertentangan dengan kalimat terdahulu, tetapi ini mengawali catatan tambahan, dalam hal ini merupakan kesimpulan. Kesimpulan itu berbunyi: kalau keselamatan kita belum tersedia di depan mata kita, maka tidak bisa tidak, kita harus menantikannya dengan tekun. ${ }^{121}$

Kemudian dilanjutkan dengan kata jika, yang dipakai kata $\varepsilon l(e i)$ yang bisa diterjemahkan jika, karena, bahwa, apakah, umpamanya. ${ }^{122}$ Karena dengan modus Indicative, maka kalimat ini juga dapat diterjemahkan tetapi karena kita mengharapkan apa yang tidak kita lihat, kita menantikannya dengan tekun.

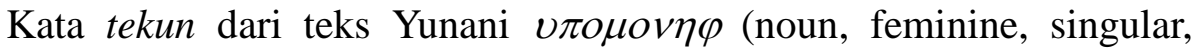

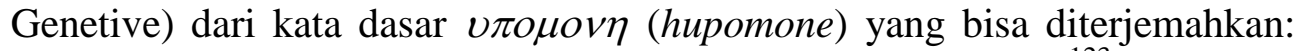
ketekunan, kesabaran, ketabahan, ketekunan menantikan. ${ }^{123}$ Kata ini didahului dengan kata menantikan yang bisa diartikan menantikan dengan sungguh-sungguh dengan ketekunan. Hagelberg menjelaskan bahwa tidak ada ketekunan yang tidak diawali dengan kesengsaraan. Ketekunan disediakan bagi kita sebagai hasil kesengsaraan. Orang yang menolak

\footnotetext{
117 Hasan Sutanto, Perjanjian Baru Interlinear Yunani-Indonesia Jilid II..., 153

118 Van Den End, Surat Roma..., 446

119 Olla Tuluan, Bahasa Yunani I..., 16

120 Van Den End, Surat Roma..., 448

121 Ibid.

122 Hasan Sutanto, Perjanjian Baru Interlinear Yunani-Indonesia Jilid II..., 242

123 Ibid., 782
} 
kesengsaraan dengan mengeluh dan mencari jalan keluar sendiri tidak akan memperoleh ketekunan. ${ }^{124}$ Kata ini artinya lebih daripada kesabaran. Kata ini berarti semangat yang dapat mengalahkan dunia; berarti tidak secara pasif menahan sabar tetapi secara aktif mengatasi godaan dan kesengsaraan hidup. ${ }^{125}$ Kata tekun dalam bahasa Yunani serumpun dengan kata hupomenein yang diartikan bertahan atau bersabar, namun ketekunan itu tidak bersifat pasif. Lebih tepat jika diterjemahkan ketahanan atau keuletan.

Dapat disimpulkan arti kata dasar hupomone adalah hal tidak mudah putus asa disertai kemauan keras untuk mencapai tujuan dan cita-cita; ketabahan dan kekerasan hati; kecakapan dan kegiatan yang bersungguh-sungguh; kecakapan dan ketahanan dalam berjuang. ${ }^{126} \mathrm{Jadi}$ kedua istilah itu, tekun dan sabar mempunyai pengertian yang saling mendukung, sebab dalam upaya menghadapi rintangan, orang percaya membutuhkan keduanya. Orang percaya tidak bersemangat mengatasi penderitaan kalau tidak ada ketekunan, dan orang percaya tidak sanggup mengatasi penderitaan kalau tidak ada kesabaran.

Dengan demikian, dalam bagian ketiga ini menjelaskan bahwa orang yang percaya kepada Tuhan memiliki keselamatan yang pasti yaitu pengharapan. Hal ini menunjukkan bahwa Allah yang menyelamatkan manusia dari kuasa dosa, Allah yang sama juga yang memberikan pengharapan bagi setiap orang yang percaya kepada-Nya. Dan hal ini didapatkan jika setiap orang percaya menantikannya dengan penuh ketekunan.

\section{BAB III}

\section{IMPLIKASI BAGI GEREJA TUHAN MASA KINI}

Ada tiga implikasi yang penulis akan paparkan dalam bab tiga ini, yakni:

\section{Implikasi Eskatologis}

Berdasarkan eksegese Roma 8:18-25, penulis memperbolehkan implikasi eskatologis yaitu:

1) Ada penderitaan selama orang percaya masih tinggal di dalam dunia ini, namun Allah mempunyai maksud dan tujuan melalui penderitaan yang

124 Dave Hagelberg, Tafsiran Roma..., 93

125 William Barclay, Pemahaman Alkitab Setiap Hari..., 114

126 Van Den End, Surat Roma..., 107 
dialami oleh setiap orang percaya, Allah ingin menunjukkan bahwa ada kemuliaan di dalamnya (Rm. 8:18).

2) Dalam menantikan kedatangan Kristus yang kedua kali (parusia) Allah melibatkan orang percaya dalam tugas dan tanggung jawab sebagai orang percaya yaitu memberitakan Injil Kristus walaupun di dalamnya ada penderitaan.

3) Bagi kita orang percaya, kehidupan bukanlah suatu yang membosankan atau suatu penantian yang sia-sia melainkan suatu pengharapan yang hidup dan mendebarkan hati.

4) Orang percaya terlibat langsung dalam situasi seluruh umat manusia. Di dalam dirinya, ia harus berjuang melawan tabiatnya sendiri yang jahat. Di luar dirinya, ia harus hidup di dalam suatu dunia kematian atau kebinasaan, namun demikian orang percaya tidak hanya hidup di dalam dunia, ia juga hidup di dalam Kristus. Yang dilihat bukan hanya dunia, melainkan ia harus melihat di seberang sana, yaitu kepada Allah. Ia tidak hanya melihat konsekuensi dosa manusia, tetapi ia juga melihat kuasa dari kemurahan dan kasih Allah.

5) Dan akhir dari semua itu bagi orang percaya adalah pengharapan. Oleh karena itu, kata kunci untuk kehidupan orang percaya adalah selalu berpengharapan dan tidak pernah putus asa. Pengharapan-lah yang memberi kita kekuatan untuk bertahan, sebab pengharapan itu selalu memperhatikan dunia yang akan datang yaitu kemuliaan dan membuat kita tetap ingat akan dunia yang akan datang itu. Oleh karena itu dalam menantikan kedatangan Kristus yang kedua sebagai orang percaya kita harus tetap tekun dan tetap berpengharapan kepada Tuhan (Rm. 8:25), kehidupan adalah keinginan menyongsong kemerdekaan, pembaharuan dan ciptaan baru yang dibuat oleh kemuliaan dan kuasa Allah.

\section{$\underline{\text { Implikasi Misiologis }}$}

Berdasarkan pengajaran Alkitab tentang penderitaan, memberikan implikasi misiologis bagi kehidupan orang percaya. Allah sebagai sumber misi melibatkan semua orang percaya dalam pelayanan misi sehingga diharapkan kepada semua orang percaya mempunyai beban dalam menjalankan misi-Nya dengan memberitakan kabar sukacita kepada orang-orang yang belum mengenal dan percaya kepada Yesus Kristus. Orang percaya harus memberitakan Injil kepada semua orang, supaya akhirnya orang lain juga dapat menikmati pengharapan kemuliaan yang mereka harapkan. Ini adalah tugas orang percaya pada masa kini yang harus dijalankan sebagai amanat agung Tuhan Yesus (Mat. 28:19-20). Memang orang percaya diperhadapkan dengan penderitaan, nyeri, kekecewaan, 
kemiskinan, penganiayaan, kesusahan dan lain sebagainya, namun yang perlu diingat bahwa semua itu tidak berarti jika dibandingkan dengan berkat, hak istimewa, dan kemuliaan yang akan dianugerahkan kepada orang percaya ( 2 Kor. 4:17). Oleh sebab itu yang harus dilakukan orang percaya adalah tetap bertahan dalam penderitaan, tidak putus asa ketika mengalami penderitaan, sabar dalam menghadapi penderitaan dan yang utama tetap mempunyai pengharapan di dalam Yesus Kristus. Sehingga melalui penderitaan yang dialami justru setiap orang percaya mengalami pertumbuhan iman. Dengan cara inilah misi Allah dapat dijalankan dalam setiap kehidupan orang percaya pada masa kini. Melalui ketekunan, kesabaran, dan kesetiaan orang percaya dalam menghadapi penderitaan, menjadikan teladan hidup yang baik bagi orang-orang yang belum mengenal Yesus. Sehingga melaluinya mereka melihat terang Kristus ada dalam kehidupan orang percaya yang bertahan dalam penderitaan.

\section{Implikasi Theologis}

Berdasarkan pengajaran Alkitab tentang penderitaan memberikan implikasi theologis bahwa penderitaan akan berlangsung terus-menerus dalam kehidupan di dunia ini, baik itu dialami orang percaya maupun kehidupan manusia pada umumnya. Oleh sebab itu orang percaya perlu menyikapi apa makna penderitaan yang dialami oleh orang percaya pada saat mengabdi kepada Tuhan. Tuhan Yesus dalam Matius 24:6-13 menjelaskan bahwa kesudahan dunia bukan diakibatkan karena penderitaan, namun semuanya itu harus terjadi yaitu: akan ada kelaparan, gempa bumi di berbagai tempat dan semuanya itu barulah permulaan penderitaan menjelang zaman baru. Selain itu akan terjadi penyiksaan, pembunuhan, kebencian, perang dan nabi-nabi palsu yang menyesatkan dan banyak orang murtad. Hal ini telah difirmankan, juga harus tergenapi karena perkataan Allah berkuasa dan segala yang terjadi berada dalam otoritas-Nya. Tetapi orang yang bertahan sampai pada kesudahannya akan berkemenangan, dengan kata lain setiap orang percaya yang bertahan dalam penderitaan-penderitaan dikarenakan melakukan pelayanan untuk Kristus pada kesudahannya akan selamat dan hidup dalam kerajaan Allah, bahkan menerima kebahagiaan hidup kekal (Rm. 8:18-25).

Oleh sebab itu, orang percaya diharapkan semakin mengerti apa yang dikehendaki Allah selama menjalani kehidupan di dunia ini yaitu orang percaya dipanggil untuk mengikuti Kristus dalam teladan-Nya menanggung penderitaan karena hidup kudus (1 Pet. 2:19-21). Mengalami penderitaan itu melibatkan ketekunan dan ketaatan akan pengharapan yang pasti yaitu hidup kekal bersama Kristus. 


\section{SIMPULAN}

Penderitaan adalah kata yang sering dihindari oleh manusia termasuk orang percaya. Selain itu situasi zaman sekarang yang semakin menekan umat manusia, seperti yang dikatakan Tuhan Yesus bahwa zaman akhir dunia ini ditandai bukan oleh perdamaian, melainkan oleh peperangan yang bertambah-tambah (Mat. 24:6). Banyak martir di negara-negara komunis yang menjadi korban kekerasan dan penindasan, yang mengakibatkan penderitaan. Mengenai Indonesia, meskipun bukan negara komunis atau negara terlarang untuk Injil, namun ratusan gereja telah dirusak dan dibakar, yang mengakibatkan korban yang cukup banyak.

Ada cukup banyak kesaksian tentang penderitaan orang percaya karena iman mereka kepada Kristus, namun tidak dapat dipungkiri bahwa masih banyak orang percaya yang belum memahami arti penderitaan itu. Hal ini nampak pada seringnya jemaat disuguhkan Firman Tuhan yang menawarkan kesenangan hidup belaka, tanpa harus mengalami penderitaan. Karena itu mereka lebih banyak melarikan diri, putus asa dan kecewa ketika mengalami penderitaan, padahal sesungguhnya penderitaan tidak dapat dihindari, namun yang dimaksudkan penulis adalah cara menanggapi penderitaan itu harus sesuai dengan apa yang Tuhan ajarkan, yaitu bahwa penderitaan yang dialami manusia itu tidak sebanding dengan kemuliaan yang akan dinyatakan (Rm. 8:18).

Paulus menegaskan bahwa bahwa orang percaya akan mengalami penderitaan, namun penderitaan itu hanya sedikit atau sebagian kecil dari kemuliaan yang akan dinyatakan. Penderitaan dan hawa nafsu terjadi

karena dunia ini memang berdosa. Penderitaan yang diderita umat manusia terjadi setelah kejatuhan manusia ke dalam dosa. Masa sekarang ini semuanya jahat, diwarnai oleh dosa, kematian dan kebinasaan. Suatu ketika akan datang hari Tuhan, yaitu hari penghakiman, ketika dunia akan digoncangkan sampai ke dasarnya; tetapi sesudah itu akan datang suatu dunia baru. Ketika Paulus menggambarkan ini, ia memakai pengertian yang setiap orang Yahudi sudah mengenal dan mengerti. Ia berbicara tentang masa sekarang dan tentang kemuliaan yang akan dinyatakan. Dengan demikian, yang dimaksud Paulus dalam bagian ini adalah keyakinan kita bahwa penderitaan sekarang tidak sebanding dengan kemuliaan yang akan datang yang akan dinyatakan kepada kita orang yang percaya kepada-Nya. Jadi penderitaan yang kita tanggung sebagai pengikut Kristus menunjukkan keikutsertaan kita dalam penderitaan Kristus, dan dapat disebut juga "menggenapkan apa yang belum tercakup dalam penderitaan Kristus", supaya kita dapat bersekutu dengan Kristus dalam penderitaan-Nya. Dengan demikian pengharapan di sini berarti harapan adanya suatu keyakinan dan kepastian bahwa orang percaya akan dibebaskan atau 
dimerdekakan dari kesia-siaan. Tuhan telah mengaruniakan Roh Kudus sebagai jaminan pemberian lebih besar yang akan diterima di masa depan. Inilah pengharapan orang percaya, yaitu penantian penuh keyakinan akan berkat-berkat yang dijanjikan yang sekarang belum ada atau belum tampak.

Tidak ada ketekunan yang tidak diawali dengan penderitaan. Ketekunan disediakan bagi kita sebagai hasil penderitaan. Orang yang menolak penderitaan dengan mengeluh dan mencari jalan keluar sendiri tidak akan memperoleh ketekunan.

\section{DAFTAR PUSTAKA}

Barclay, William

1986 Pemahaman Alkitab Setiap Hari - Roma. Jakarta: BPK Gunung Mulia

Berkhof, Louis

1995 Teologia Sistematika, Doktrin Manusia Vol. 2. Jakarta: LRI

Cranfield, C. E. B.

1975 A Critical and Exegetical Commentary on the Epistle to the Romans. Edinburgh: The International Commentary, Clark Limited

Dunn, James D. G.

1988 Word Biblical Commentary Roman 1-8. Dalas, Texas: Word Book Publisher

End, Van den

2003 Surat Roma. Jakarta: BPK Gunung Mulia

Greenlee, J. Harold

1979 A Consice Exegetical Grammer of New Testament Greek.

Michigan: W. B. Eerdemand Publishing Company

Hagelberg, Dave.

1998 Tafsiran Roma. Bandung: Yayasan Kalam Hidup

Hoekema, Anthony

2003 Manusia: Ciptaan Menurut Gambar Allah. Surabaya: Momentum 
Hadiwijono, Harun

$2000 \quad$ Iman Kristen. Jakarta: Gunung Mulia

Herlianto

1993 Teologia Sukses antara Allah dan Mamon. Jakarta: BPK Gunung Mulia

H. E, Theodore

1991 Mengapa Orang-Orang Kristen Menderita. Jakarta: Mimery Press

Handoko, Yakub Tri

2007 Theologia Kemakmuran. Tenggilis Mejoy: Sekolah Alkitab Malam GKKA

Lempp, Walter

1987

Tafsiran Alkitab Kejadian 1:1 - 4:26. Jakarta: BPK Gunung Mulia

Michaeli, Frank

1972 Bagaimana Memahami Perjanjian Lama. Bandung: Kalam Hidup

M, Barclay

2002 Kamus Yunani-Indonesia. Jakarta: BPK Gunung Mulia

Nahuway, Yakub

1990 Jalan ke Surga telah Ada. Jakarta: GBI Mawar Saron

Pfeiffer, Charles F. \& Everett F. Harrison

2004 Tafsiran Alkitab Wycliffe Vol I. Malang: Gandum Mas

Sutanto, Hasan

2003 Perjanjian Baru Interlinear Yunani-Indonesia Jilid III. Jakarta: Lembaga Alkitab Indonesia

Teguh Sutandio, Denny

t.t. Hidup oleh Roh dan Pengharapan Anak-anak Allah, http://www.dgip-go.id/ebscript/publicportal.cgi

Tulluan, Olla

2002 Bahasa Yunani I. Batu: Departemen Literatur YPPII 
Y., Setiyardi, Tomi Aryanto, \& Ayu Cipta

2004 Majalah Tempo, Edisi 21 November

Zodhiates, Spiros

1993 The Complete Word Study Dictionary of New Testament. Chattanoga: AMG Publisher 